\title{
Ultimate Load Behaviour of Perforated Steel Plate Girders with Inclined Stiffeners
}

\author{
Kelakuan Beban Muktamad Galang Plat Keluli Berlubang dengan Pengukuh Condong
}

Mohd Yazmil Md. Yatim*, Mohd Reza Azmi, Lau Yew Ling, Muhammad ‘Ariff Putra Ansaruddin Agus \& Nur Farhana Nadira Sazali

ABSTRACT

This paper is concerned with the ultimate load behaviour of perforated thin-webbed steel plate girders with inclined web stiffeners. Non-linear modelling and analyses were carried out on simply supported plate girders using a commercial finite element software, LUSAS. The girders are of practical size and subjected to a single concentrated load applied at the centre of gravity of the section. Effects of inclination degree of stiffeners and central web openings on the performance and behaviour of such girders are investigated. Variations of ultimate strength, failure characteristic and load-deflection response are obtained from the analyses. The load carrying capacity is found to increase significantly when the inclined intermediate stiffeners were provided to the girders; to the extent of 38\% for the unperforated girders whilst $45 \%$ for those having web openings. Reduction of shear strength due to presence of web openings may also be improved from $56 \%$ in the girders stiffened vertically to only $24 \%$ in the girders provided with inclined stiffeners of $30^{\circ}$.

Keywords: Slender girder; web opening; inclined stiffener; non-linear analysis; ultimate load behaviour

ABSTRAK

Kertas ini adalah tentang kelakuan beban muktamad galang plat keluli berweb nipis yang berlubang dengan pengukuh web condong. Permodelan dan analisis tidak linear telah dijalankan ke atas galang plat tersokong mudah dengan menggunakan perisian komersil unsur terhingga, LUSAS. Saiz galang-galang tersebut adalah praktikal dan dikenakan beban tumpu tunggal pada pusat graviti keratan. Kesan-kesan seperti darjah kecondongan pengukuh dan bukaan web terhadap prestasi dan kelakuan galang terbabit dikaji. Pelbagai variasi kekuatan muktamad, ciri kegagalan dan respons bebanpesongan diperolehi daripada analisis. Kapasiti tanggungan beban oleh galang didapati meningkat dengan signifikan apabila pengukuh condong digunakan; sehingga 38\% untuk galang tanpa bukaan sementara 45\% untuk galang dengan bukaan web. Pengurangan kekuatan ricih yang disebabkan oleh bukaan web dapat ditambah baik daripada 56\% bagi galang terkukuh menegak kepada hanya $24 \%$ bagi galang dengan pengukuh condong $30^{\circ}$.

Kata kunci: Galang langsing; bukaan web; pengukuh condong; analisis tidak linear; kelakuan beban muktamad

INTRODUCTION

Plate girders are employed in structural applications whenever the largest commercially available rolled sections are still inadequate to carry high in-plane bending moments associated with large shearing forces over long spans. The slender webs in plate girders are prone to local and shear buckling at relatively low shear and thus, need be stiffened to increase the shear resistance of the web. Analysis and design of plate girders incorporate post-buckling reserve of strength which resists applied forces considerably in excess of the initial buckling load. Once a web plate has lost its capacity, further increase in compressive load does not cause sudden collapse of the girder. The thin web sustains additional compressive stress through development of inclined membrane which anchors against the top and bottom flanges, resulting in formation of buckle patterns. Such load carrying mechanism is called tension field action that contributes significantly to the ultimate capacity of plate girders.
Provisions of intermediate transverse stiffeners at certain intervals, in addition to preventing the torsion of flanges, serve as boundaries for the development of tensile membrane in the slender web. Through many years, studies on the ultimate load behaviour of transversely stiffened plate girders were extensive in order to establish the philosophy and design procedures (Basler \& Thurlimann 1960, Rockey \& Skaloud 1971, Porter et al. 1975, Narayanan \& Adorisio 1983, Lee \& Yoo 1998, Yoo \& Lee 2006). In addition, the stability of a web plate can also be enhanced by subdividing the individual panels with longitudinal stiffeners. Studies have been carried out in the past in order to determine the number, dimensions and positioning of the longitudinal stiffeners in a particular web panel for optimum performance of steel plate girders (Nishino \& Okumura 1968, Rockey et al. 1978, Horne \& Grayson 1983, Graciano \& Edlund 2002, Alinia \& Moosavi 2008). However, those dealing with inclined stiffeners are not many and seem to require more attention.

Plate girders with web openings have found increasing popularity in civil engineering constructions due to 
their beneficial characteristics of providing spaces for services, inspection and periodic maintenance. This form of construction results in reduced floor height, systematic installation of pipes or ducts and cost-effectiveness but at the same time, causes penalty on the shear strength of the girders depending on the parameters of the openings. The loss of strength can be restored by reinforcing the openings using steel flats or bars which is costly and complicate the fabrication process (Lian \& Shanmugam 2003).

Use of inclined stiffeners result in unequal diagonal length and unequal subdivisions of web panels at the top compression and bottom tension flanges. Inclined stiffeners would also have the advantage of limiting the shear factor without requiring the expensive addition of longitudinal stiffeners (Guarnieri 1985). Therefore, there may be variations in the post-buckling strength and failure characteristic of plate girders due to effects of the inclination. Such variations need to be investigated in order to enhance understanding of the behaviour of stiffened plate girders. Non-linear finite element investigation on such girders has, therefore, been undertaken using a finite element package. Attention is focused on aspects such as inclination angle of the stiffeners as well as the web opening shape and size in order to highlight the benefits of using inclined stiffeners over the conventional vertical stiffeners. Details of the numerical modelling are reported herein along with the results obtained.

\section{FINITE ELEMENT ANALYSIS}

\section{FINITE ELEMENT MODEL}

Three-dimensional finite element models were developed by using LUSAS package. Non-linear analyses were carried out on 55 plate girder models having different degrees of inclined stiffeners and configurations of web openings. These girders are basically modified from the girder SPG 1 tested in the past by Shanmugam and Baskar (2003) in order to suit the intentions and objectives of the study. Stiffeners were placed accordingly on both sides of the web plate, thus subdividing the thin web into four web panels. Vertical stiffeners are placed at the mid-span to prevent premature failure due to local buckling. Different angles of inclination, $\theta$ viz., $30^{\circ}$ to $90^{\circ}$ in the increment of $15^{\circ}$, are considered for the intermediate stiffeners in the girders. Two shapes of centrally located web openings viz., square and circular having diameter, $d_{0}$ of $0.1 d, 0.2 d, 0.3 d, 0.4 d$ and $0.5 d$, are accounted for in this study. The basic dimensions were kept the same in all girders in order to have a constant span length, $L=4680 \mathrm{~mm}$, depth of web panel, $d=750 \mathrm{~mm}$, thickness of web, $t_{w}=3 \mathrm{~mm}$, flange width, $b_{f}=200 \mathrm{~mm}$, flange thickness, $t_{f}=20 \mathrm{~mm}$ and web slenderness ratio, $d / t=250$. Details of the models developed for verification and for the present study, and the corresponding material properties are presented in Tables 1 and 2, respectively.

\section{ELEMENT}

Various types of elements are available in the LUSAS element library. Proper selection of elements is important as they dictate the behaviour of the model. The geometries of web, flanges and stiffeners were meshed with three-dimensional quadrilateral shell elements. Each of the elements consists of four corner and four intermediate nodes. The element formulation takes account of membrane, flexural and transverse shear deformations which are suitable for thin wall applications. A consistent formulation of the tangent stiffness makes this element particularly effective in geometrically non-linear treatment. The quadrilateral elements use an assumed strain field to define transverse shear which ensures that the element does not lock when it is thin. The element comprises six degrees of freedom viz., translations and rotations with respect to global axes at each node.

$$
\text { MESH }
$$

In order to confirm the accuracy of the modelling, comparisons of results for the original girders have been made with the corresponding experimental values. Regular finite element mesh with division size of $50 \times 50 \mathrm{~mm}$ was adopted in all the analysis. It was chosen largely based on convergence studies carried out to determine the optimal element size that produces a relatively accurate solution in terms of strength and behaviour within an acceptable computational time. However, irregular mesh was allowed for at the web surfaces due to effect of inclination of the intermediate stiffeners. A typical finite element model is displayed in Figure 1.

TABLE 1. Details of plate girders tested by other researchers

\begin{tabular}{|c|c|c|c|c|c|}
\hline Girder & $\begin{array}{l}\text { Inclination angle } \\
\text { of stiffeners, } \theta\end{array}$ & $\begin{array}{l}\text { Shape of web } \\
\text { openings }\end{array}$ & $\begin{array}{l}\text { Diameter of web } \\
\text { openings, } d_{0}(\mathrm{~mm})\end{array}$ & $\begin{array}{c}\text { Modulus of } \\
\text { elasticity, } E_{s}(\mathrm{GPa})\end{array}$ & $\begin{array}{c}\text { Average yield } \\
\text { stress, } f_{y_{(a v g)}}(\mathrm{MPa})\end{array}$ \\
\hline $\begin{array}{c}\text { SPG } 1 \\
\text { (Shanmugam \& Baskar } \\
\text { 2003) }\end{array}$ & $90^{\circ}$ & NA & NA & 200 & 277 \\
\hline $\begin{array}{c}\text { NCP } 10 \\
\text { (Narayanan \& Der } \\
\text { Avanessian 1983) }\end{array}$ & $90^{\circ}$ & Rectangular & $b_{0} \times d_{0}(300 \times 240)$ & 200 & 243 \\
\hline $\begin{array}{c}\text { CP } 4 \\
\text { (Narayanan \& Rockey } \\
\text { 1981) }\end{array}$ & $90^{\circ}$ & Circular & $0.5 d$ & 200 & 251 \\
\hline
\end{tabular}


TABLE 2. Details of plate girders in the present study

\begin{tabular}{|c|c|c|c|c|c|}
\hline Girder & $\begin{array}{l}\text { Inclination angle } \\
\text { of stiffeners, } \theta\end{array}$ & $\begin{array}{c}\text { Shape of web } \\
\text { openings }\end{array}$ & $\begin{array}{c}\text { Diameter of web } \\
\text { openings, } d_{0}(\mathrm{~mm})\end{array}$ & $\begin{array}{c}\text { Modulus of } \\
\text { elasticity, } E_{s}(\mathrm{GPa})\end{array}$ & $\begin{array}{c}\text { Average yield } \\
\text { stress, } f_{y \text { (avg) }}(\mathrm{MPa}) \\
\end{array}$ \\
\hline A90D0 & $90^{\circ}$ & \multirow{5}{*}{ NA } & \multirow{5}{*}{ NA } & \multirow{5}{*}{200} & \multirow{5}{*}{275} \\
\hline A75D0 & $75^{\circ}$ & & & & \\
\hline A60D0 & $60^{\circ}$ & & & & \\
\hline A45D0 & $45^{\circ}$ & & & & \\
\hline A30D0 & $30^{\circ}$ & & & & \\
\hline A90D1S & \multirow{5}{*}{\multicolumn{2}{|c|}{ Square }} & $0.1 d$ & \multirow{5}{*}{200} & \multirow{5}{*}{275} \\
\hline A90D2S & & & $0.2 d$ & & \\
\hline A90D3S & & & $0.3 d$ & & \\
\hline A90D4S & & & $0.4 d$ & & \\
\hline A90D5S & & & $0.5 d$ & & \\
\hline A75D1S & \multirow{5}{*}{$75^{\circ}$} & \multirow{5}{*}{ Square } & $0.1 d$ & \multirow{5}{*}{200} & \multirow{5}{*}{275} \\
\hline A75D2S & & & $0.2 d$ & & \\
\hline A75D3S & & & $0.3 d$ & & \\
\hline A75D4S & & & $0.4 d$ & & \\
\hline A75D5S & & & $0.5 d$ & & \\
\hline A60D1S & \multirow{5}{*}{$60^{\circ}$} & \multirow{5}{*}{ Square } & $0.1 d$ & \multirow{5}{*}{200} & \multirow{5}{*}{275} \\
\hline A60D2S & & & $0.2 d$ & & \\
\hline A60D3S & & & $0.3 d$ & & \\
\hline A60D4S & & & $0.4 d$ & & \\
\hline A60D5S & & & $0.5 d$ & & \\
\hline A45D1S & \multirow{5}{*}{$45^{\circ}$} & \multirow{5}{*}{ Square } & $0.1 d$ & \multirow{5}{*}{200} & \\
\hline A45D2S & & & $0.2 d$ & & \\
\hline A45D3S & & & $0.3 d$ & & 275 \\
\hline A45D4S & & & $0.4 d$ & & \\
\hline A45D5S & & & $0.5 d$ & & \\
\hline A30D1S & & & $0.1 d$ & & \\
\hline A30D2S & & & $0.2 d$ & & \\
\hline A30D3S & $30^{\circ}$ & Square & $0.3 d$ & 200 & 275 \\
\hline A30D4S & & & $0.4 d$ & & \\
\hline A30D5S & & & $0.5 d$ & & \\
\hline A90D1C & & & $0.1 d$ & & \\
\hline A90D2C & & & $0.2 d$ & & \\
\hline A90D3C & $90^{\circ}$ & Circular & $0.3 d$ & 200 & 275 \\
\hline A90D4C & & & $0.4 d$ & & \\
\hline A90D5C & & & $0.5 d$ & & \\
\hline A75D1C & & & $0.1 d$ & & \\
\hline A75D2C & & & $0.2 d$ & & \\
\hline A75D3C & $75^{\circ}$ & Circular & $0.3 d$ & 200 & 275 \\
\hline A75D4C & & & $0.4 d$ & & \\
\hline A75D5C & & & $0.5 d$ & & \\
\hline A60D1C & & & $0.1 d$ & & \\
\hline A60D2C & & & $0.2 d$ & & \\
\hline A60D3C & $60^{\circ}$ & Circular & $0.3 d$ & 200 & 275 \\
\hline A60D4C & & & $0.4 d$ & & \\
\hline A60D5C & & & $0.5 d$ & & \\
\hline A45D1C & & & $0.1 d$ & & \\
\hline A45D2C & & & $0.2 d$ & & \\
\hline A45D3C & $45^{\circ}$ & Circular & $0.3 d$ & 200 & 275 \\
\hline A45D4C & & & $0.4 d$ & & \\
\hline A45D5C & & & $0.5 d$ & & \\
\hline A30D1C & & & $0.1 d$ & & \\
\hline A30D2C & & & $0.2 d$ & & \\
\hline A30D3C & $30^{\circ}$ & Circular & $0.3 d$ & 200 & 275 \\
\hline A30D4C & & & $0.4 d$ & & \\
\hline A30D5C & & & $0.5 d$ & & \\
\hline
\end{tabular}




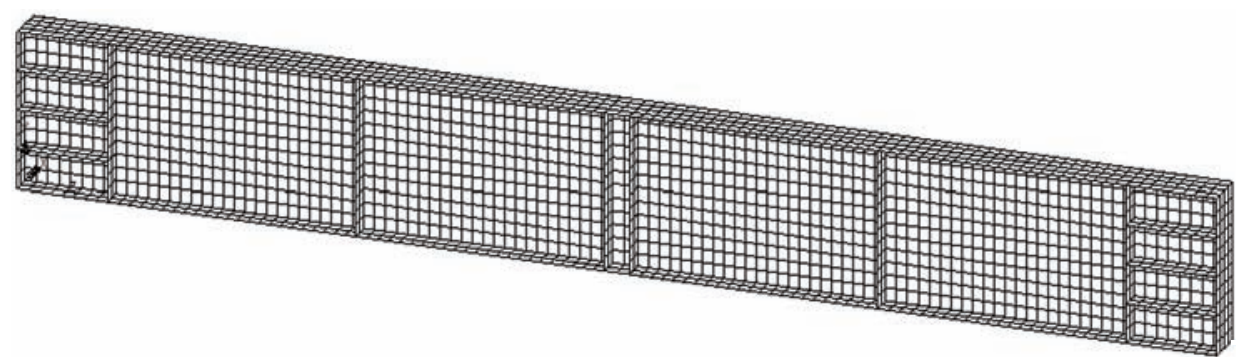

(a) Girder A90D0

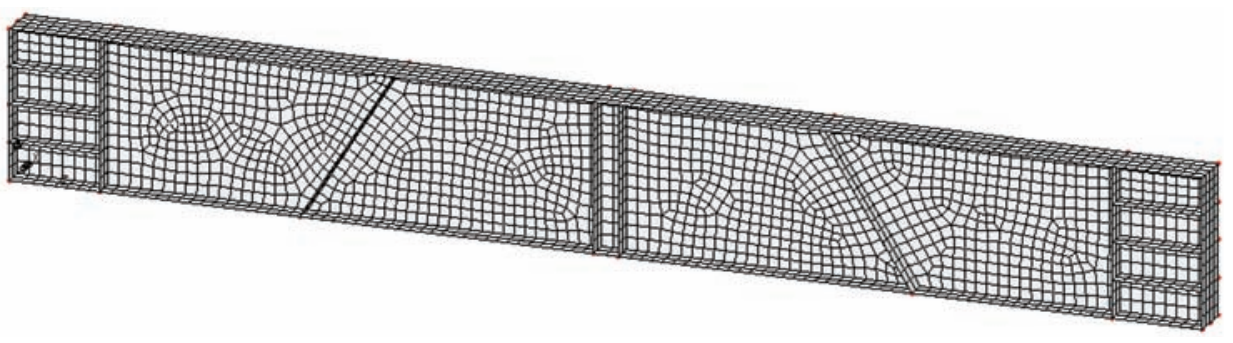

(b) Girder A60D0

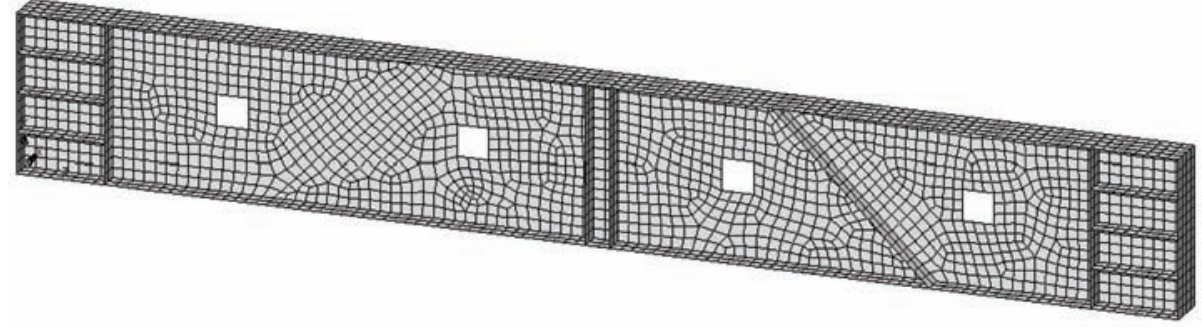

(c) Girder A45D2S

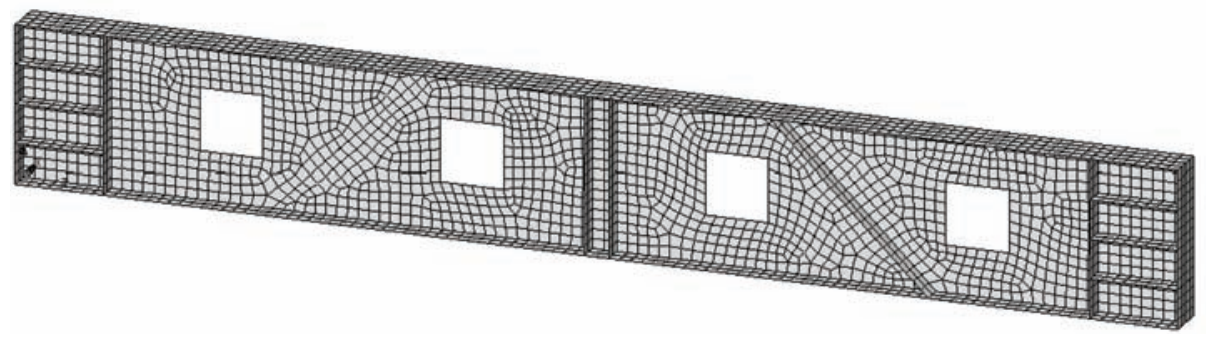

(d) Girder A45D5S

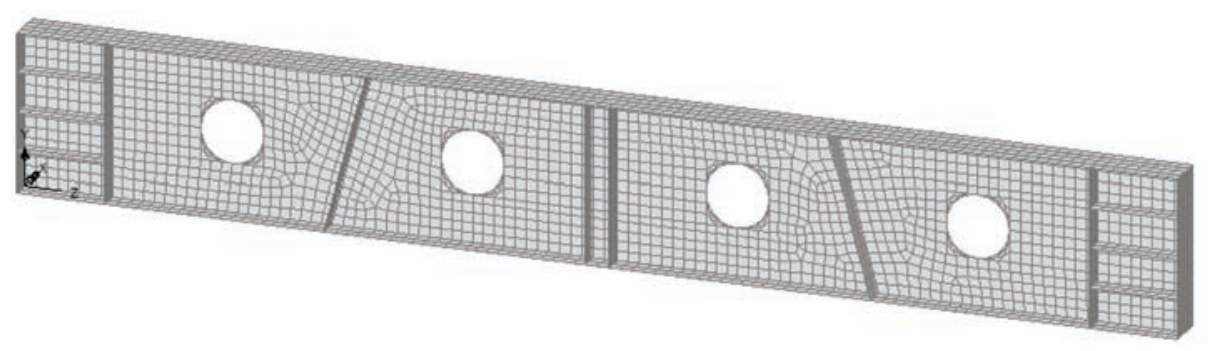

(e) Girder A75D4C 


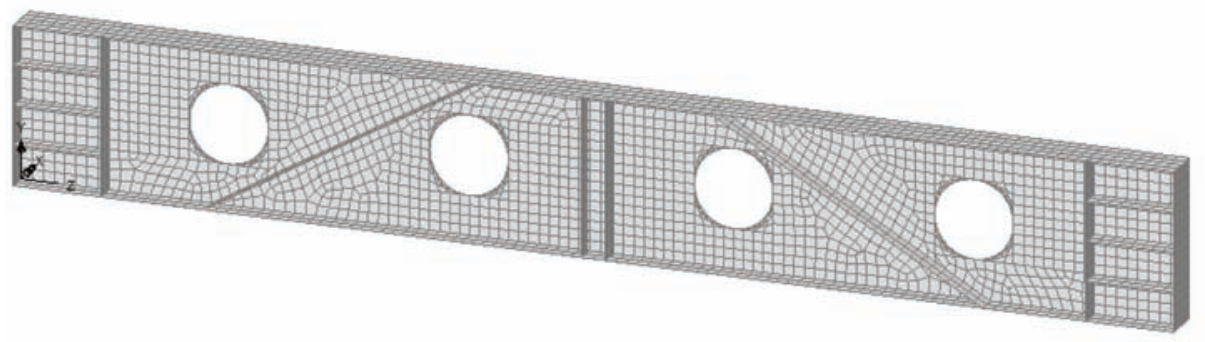

(f) Girder A30D5C

FIGURE 1. Typical finite element meshes

MATERIAL MODEL

The steel plate girders were modelled as isotropic elasticperfectly plastic materials, giving a uniaxial stress-strain relationship as shown in Figure 2. Parameters needed to define this stress potential material model are listed in Table 1. These values are taken from experimental works reported by earlier researchers (Shanmugam \& Baskar 2003, Narayanan \& Der Avanessian 1983, Narayanan \& Rockey 1981). The non-linear properties are based on Von-Mises yield criterion which represents the ductile behaviour of steel material that exhibits little volumetric strain.

\section{BOUNDARY CONDITION AND LOADING}

Detailed boundary conditions were imposed to the finite element model to reflect simple support conditions i.e., pin and roller. At the pin support, the girder was restrained against the displacements in global $x$-, $y$ - and $z$-directions but free to move along $z$-direction at the roller support. Nevertheless, rotations about all directions were allowed for in both types of support conditions. A vertical concentrated load was applied to the girder incrementally. In LUSAS, the convergence criterion is based on force and displacement. An automatic load increment with Crisfield's arc length control was selected. Newton-Raphson solution strategy with a specified number of iterations was used to provide convergence at the end of each load increment within tolerance limits. Also, load step reduction with specified reduction factor and increase factor was allowed for. This procedure has a potential to step over a difficult point in the analysis so that the solution can proceed to lead to convergence. Termination of analysis was, however, limited to the default criteria.

\section{INITIAL IMPERFECTION}

Generally, plates used in thin-walled applications are not perfectly flat but may have small initial imperfections. These initial imperfections can take the form of non-uniformity or local variations in the physical properties of the material, deviations in shape and load eccentricities (Alinia et al. 2009). Residual compressive stresses in a slender plate induced by uneven cooling after rolling or welding cause it to premature buckling. A perfectly flat and undeformed model may be stiff and basically yields different response compared to the one having imperfect geometry.

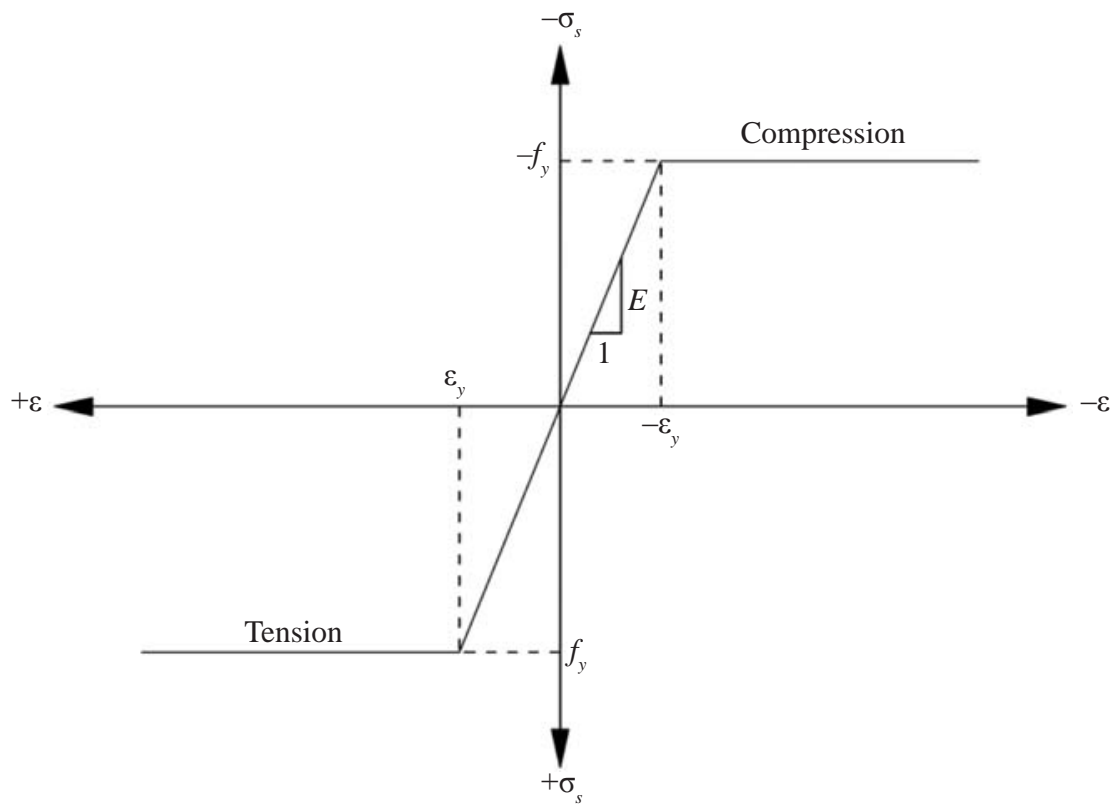

FIGURE 2. Uniaxial stress-strain relationship for steel material 
Initial imperfections can be initiated in several ways in the modelling. One method is by manually defining the appropriate geometry during pre-processing stage. Alternatively, according to Chen and Jia (2010) and Basher et al. (2011), an imperfection model can be built into the initial model by loading the results file from buckling analysis in which, the deformed mesh is considered as initially imperfect geometry of the girder. The latter technique was adopted in the present study as it is more feasible as far as geometric modelling is concerned. The buckling analysis predicts the possible deformed shapes due to structural instability. The subspace iteration algorithm available in LUSAS facilities was employed for solving the associated eigenvalue problems. Different deformed shapes or eigenvectors obtained from the buckling analysis were attempted for further non-linear analysis. From extensive trials, a mode shape from the first extracted eigenvalue was assumed as the imperfection model since it has provided satisfactory results as far as ultimate load behaviour is concerned.

\section{RESULTS AND DISCUSSION}

\section{ULTIMATE LOAD CAPACITY AND ACCURACY OF MODEL}

It is imperative to validate the models before carrying out further analysis. The assessment of the accuracy was made through comparisons between the finite element predictions and the corresponding experimental results for the girders SPG 1 (Shanmugam \& Baskar 2003), NCP 10 (Narayanan \& Der Avanessian 1983) and CP 4 (Narayanan \& Rockey 1981). Finite element analysis provided a detailed output from which the ultimate loads and deformation behaviour can be extracted. Finite element results for ultimate load, $P_{u}$ is tabulated in Table 3 along with the corresponding experimental values, $P_{u \text {, exp }}$. It is apparent from the ratio $P_{u \text {, }}$ / $P_{u \text {, exp }}$ that the finite element and experimental values are relatively close within acceptable level of accuracy, i.e., $\pm 10 \%$. Thus, it can be concluded that the proposed finite element model is capable of predicting the ultimate strength of steel plate girders with good approximation.

Ultimate loads obtained from the numerical analyses, $P_{u}$ along with the ratio $P_{u} / P_{u 0}$ are listed in Table 4 in which, $P_{u 0}$ is the ultimate load obtained for plate girder stiffened

\begin{tabular}{ccccc}
\multicolumn{4}{c}{ TABLE 3. Verification of numerical model } & \\
\hline Girder & LUSAS & Experiment & & $P_{u}$ \\
\cline { 5 - 5 } & $P_{u}(\mathrm{kN})$ & $P_{u, \text { exp }}(\mathrm{kN})$ & & $P_{u, \exp }$ \\
\hline $\begin{array}{c}\text { SPG 1 } \\
\text { (Shanmugam \& } \\
\text { Baskar 2003) } \\
\text { NCP 10 }\end{array}$ & 470 & 488 & & 0.96 \\
$\begin{array}{c}\text { (Narayanan \& Der } \\
\text { Avanessian 1983) } \\
\text { CP 4 }\end{array}$ & 130 & 143.6 & & 0.91 \\
$\begin{array}{c}\text { (Narayanan \& } \\
\text { Rockey 1981) }\end{array}$ & 86 & & \\
\hline
\end{tabular}

TABLE 4. Comparison of ultimate loads

\begin{tabular}{|c|c|c|}
\hline \multirow{2}{*}{ Girder } & \multirow{2}{*}{$P_{u}(\mathrm{kN})$} & \multirow{2}{*}{$\frac{P_{u}}{P_{u, \text { exp }}}$} \\
\hline & & \\
\hline A90D0 & $442\left(P_{\mu \nu}\right)$ & 1.00 \\
\hline A75D0 & 467 & 1.06 \\
\hline A60D0 & 494 & 1.12 \\
\hline A45D0 & 533 & 1.21 \\
\hline A30D0 & 610 & 1.38 \\
\hline A90D1S & 416 & 0.94 \\
\hline A90D2S & 362 & 0.82 \\
\hline A90D3S & 338 & 0.76 \\
\hline A90D4S & 248 & 0.56 \\
\hline A90D5S & 182 & 0.41 \\
\hline A75D1S & 436 & 0.99 \\
\hline A75D2S & 377 & 0.85 \\
\hline A75D3S & 354 & 0.80 \\
\hline A75D4S & 262 & 0.59 \\
\hline A75D5S & 208 & 0.47 \\
\hline A60D1S & 464 & 1.05 \\
\hline A60D2S & 400 & 0.90 \\
\hline A60D3S & 358 & 0.81 \\
\hline A60D4S & 290 & 0.66 \\
\hline A60D5S & 216 & 0.49 \\
\hline A45D1S & 509 & 1.15 \\
\hline A45D2S & 445 & 1.01 \\
\hline A45D3S & 372 & 0.84 \\
\hline A45D4S & 310 & 0.70 \\
\hline A45D5S & 243 & 0.55 \\
\hline A30D1S & 606 & 1.37 \\
\hline A30D2S & 585 & 1.32 \\
\hline A30D3S & 524 & 1.19 \\
\hline A30D4S & 442 & 1.00 \\
\hline A30D5S & 364 & 0.82 \\
\hline A90D1C & 424 & 0.96 \\
\hline A90D2C & 380 & 0.86 \\
\hline A90D3C & 332 & 0.75 \\
\hline A90D4C & 334 & 0.76 \\
\hline A90D5C & 244 & 0.55 \\
\hline A75D1C & 444 & 1.00 \\
\hline A75D2C & 396 & 0.90 \\
\hline A75D3C & 344 & 0.78 \\
\hline A75D4C & 320 & 0.72 \\
\hline A75D5C & 264 & 0.60 \\
\hline A60D1C & 472 & 1.07 \\
\hline A60D2C & 422 & 0.95 \\
\hline A60D3C & 370 & 0.84 \\
\hline A60D4C & 320 & 0.72 \\
\hline A60D5C & 290 & 0.66 \\
\hline A45D1C & 512 & 1.16 \\
\hline A45D2C & 472 & 1.07 \\
\hline A45D3C & 414 & 0.94 \\
\hline A45D4C & 358 & 0.81 \\
\hline A45D5C & 342 & 0.77 \\
\hline A30D1C & 608 & 1.38 \\
\hline A30D2C & 596 & 1.35 \\
\hline A30D3C & 568 & 1.29 \\
\hline A30D4C & 512 & 1.16 \\
\hline A30D5C & 458 & 1.04 \\
\hline
\end{tabular}


vertically $\left(\theta=90^{\circ}\right)$ and without web openings. For the unperforated girders, it is clear from the table that the ultimate load increased significantly when the inclined stiffeners were used in place of the vertical stiffeners. For example, the ultimate load carrying capacity has been improved by $12 \%$ and $38 \%$ when the stiffeners were made inclined by $60^{\circ}$ and $30^{\circ}$, respectively. In the girders with centrally located square web openings, the ultimate strength shows $56 \%$ reduction when the size of openings were enlarged from $0.1 d$ to $0.5 d$ for the girder with intermediate vertical stiffener, whilst those with inclined stiffeners, the percentage drop from $52 \%(\theta=$ $\left.75^{\circ}\right)$ to only $39 \%\left(\theta=30^{\circ}\right)$. This indicates the effectiveness of inclined stiffeners as alternative element to restore the loss of strength in the perforated girders. Moreover, the load carrying capacity of the girder with $30^{\circ}$ inclined stiffeners remained unaffected even though the opening size as large as $0.4 d$ was introduced in the web panel. These portray the advantage of using inclined stiffeners as stiffening element for thin webs. Variations of ultimate strength for the girders containing circular web openings, however, exhibit similar pattern as those having square web openings.

Figure 3 shows the typical predicted deformed shapes of the girders at failure load. In all the girders, after reaching the elastic critical load, the web panels started to buckle along the diagonal parallel to the tensile direction, indicating the formation of tension field. Further loading in the postbuckling stage was resisted by tensile membrane action, leading to increase in out-of-plane deformation of the web due to shear. At this stage, the increase in applied load gives rise to the corresponding vertical displacement larger compared to that in the elastic phase. Formation of typical plastic hinges in the top and bottom flanges can be observed in Figure 4. The stiffeners at the support were strong enough to anchor the horizontal and vertical components of the diagonal tensile force. Hinges that formed in the flanges were caused by the vertical component of the pulling force from the tension field. The central portion of the girder between the internal hinges remained straight and horizontal instead of being curved in elevation as in the normal beam behaviour.
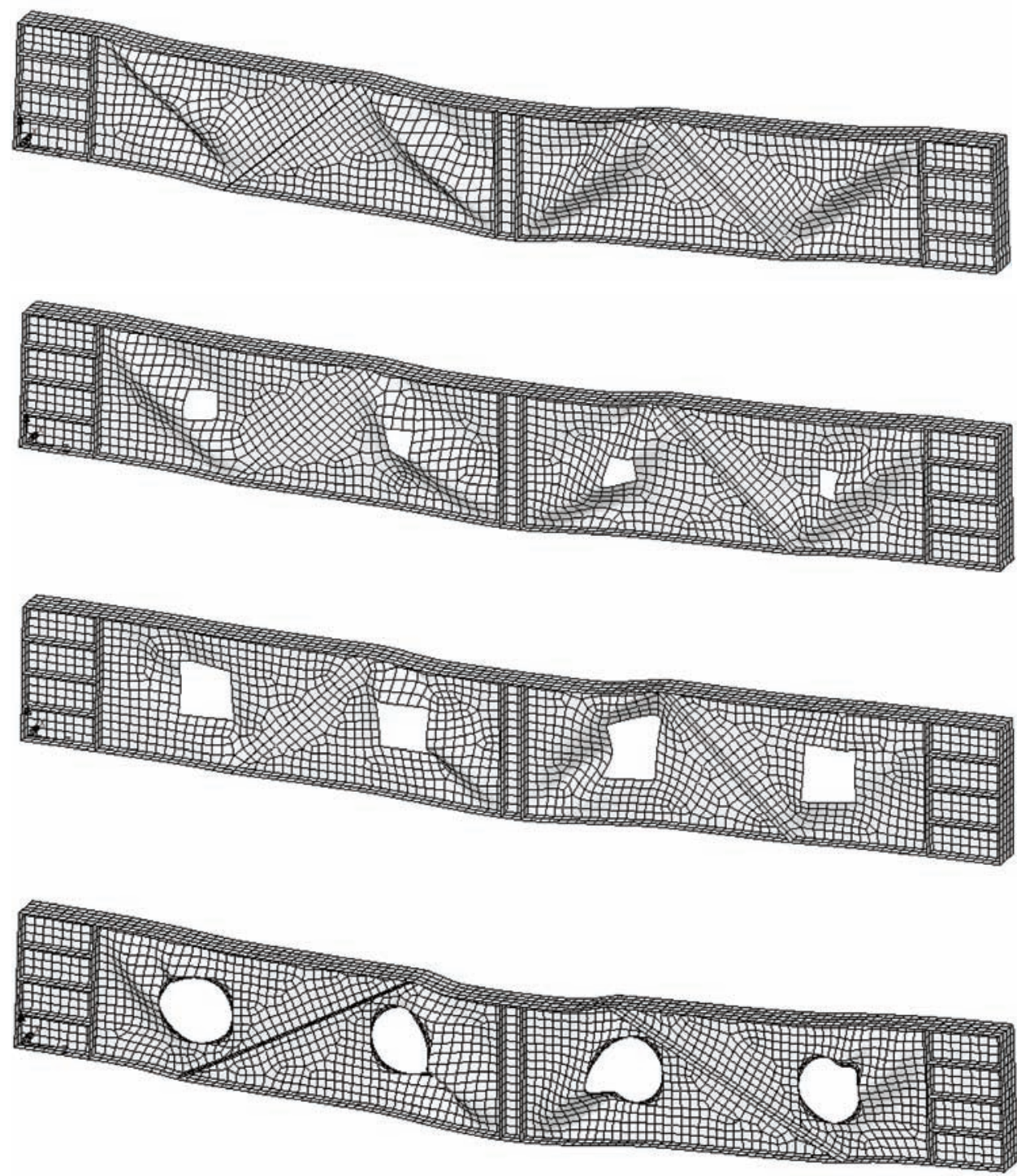

FIGURE 3. Typical deformation of girders at failure 


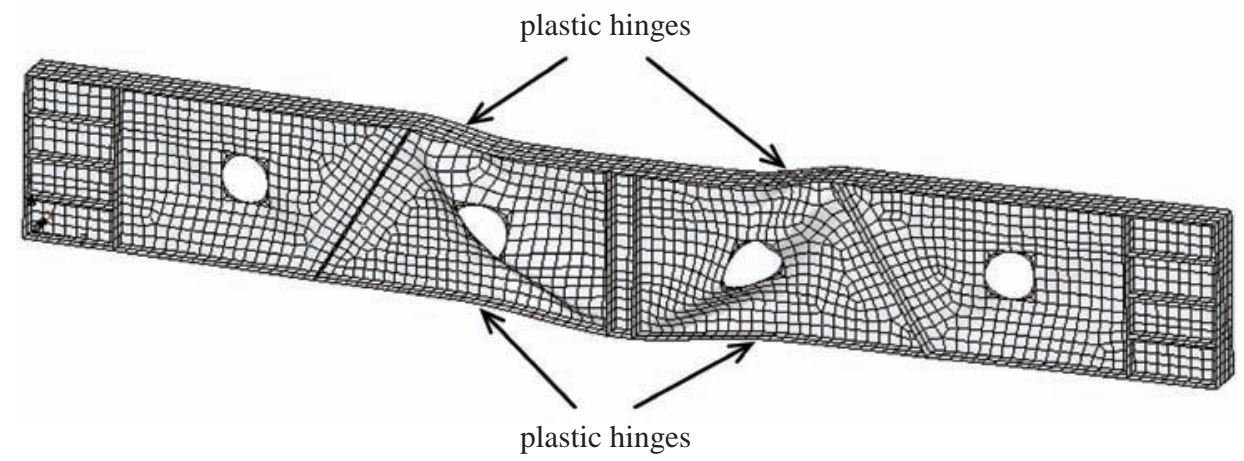

FIGURE 4. Typical formation of plastic hinges

The accuracy of the models has been ascertained through comparison with the available experimental results at the initial stages of modelling particularly the original girder with intermediate vertical stiffeners and without web openings, hence it is assumed that predictions for other models with inclined intermediate stiffeners are considerably correct. However, further experimental and analytical works as well as design recommendations are essential in order to understand the mechanisms clearly and add significantly to knowledge of the related fields.

\section{CONCLUSIONS}

Non-linear finite element analysis has been carried out on simply supported thin-webbed steel plate girders with inclined intermediate stiffeners. Results have shown the variations of ultimate strength and behaviour at failure. Different degrees of inclination angles of the stiffeners, sizes of web openings and shapes of web openings are accounted for in this numerical study. It can be concluded from the findings that use of inclined stiffeners affects significantly the load carrying capacity of plate girders. This preliminary study has, therefore, provided some general insights regarding the ultimate load behaviour of plate girders having inclined stiffeners and thus, further analysis on stiffeners with inclination angle lower than $30^{\circ}$ may be looked into. In addition, experimental investigations and detailed theoretical works are strongly recommended.

\section{ACKNOWLEDGEMENTS}

The works described were supported by generous research grants; Dana Impak Perdana (DIP-2015-006), Geran Galakan Penyelidik Muda (GGPM-2015-015) and Geran Arus Perdana (AP-2015-011) the authors acknowledge the facilities provided by the Department of Civil and Structural Engineering, Universiti Kebangsaan Malaysia.

\section{REFERENCES}

Alinia, M. M. \& Moosavi, S. H. 2008. A parametric study on the longitudinal stiffeners of web panels. Thin-Walled Structures 46: 1213-1223.
Alinia, M. M., Gheitasi, A. \& Erfani, S. 2009. Plastic shear buckling of unstiffened stocky plates. Journal of Constructional Steel Research 65: 1631-1643.

Basher, M., Shanmugam, N.E. \& Khalim, A.R. 2011. Horizontally curved composite plate girders with trapezoidally corrugated webs. Journal of Constructional Steel Research 67: 947-956.

Basler, K. \& Thurlimann, B. 1960. Carrying Capacity of Plate Girders. Preliminary Publication, $6^{\text {th }}$ Congress of International Association for Bridge and Structural Engineering (IABSE) 16.

Chen, S. \& Jia, Y. 2010. Numerical investigation of inelastic buckling of steel-concrete composite beams prestressed with external tendons. Thin-Walled Structures 48: 233242.

Graciano, C. A. \& Edlund, B. 2002. Nonlinear FE analysis of longitudinally stiffened girder webs under patch loading. Journal of Constructional Steel Research 58: 1231-1245.

Guarnieri, G. 1985. Collapse of plate girders with inclined stiffeners. Journal of Structural Engineering ASCE 111(2): 378-399.

Horne, M. R. \& Grayson, W. R. 1983. The ultimate load behaviour of longitudinally stiffened web panels subjected to shear stress. Proceedings of the Institution of Civil Engineers 75(2): 175-203.

Lee, S. C. \& Yoo, C. H. 1998. Strength of plate girder web panels under pure shear. Journal of Structural Engineering ASCE 124(2): 184-194.

Lian, V. T. \& Shanmugam, N. E. 2003. Openings in horizontally curved plate girder webs. Thin-Walled Structures 41: 245-269.

Narayanan, R. \& Adorisio, D. 1983. Model studies on plate girders. Journal of Strain Analysis 18(2): 111-117.

Narayanan, R. \& Der Avanessian, N.G.V. 1983. Equilibrium solution for predicting the strength of webs with rectangular holes. Proceedings of the Institution of Civil Engineers 75(2): 265-282.

Narayanan, R. \& Rockey, K.C. 1981. Ultimate load capacity of plate girders with webs containing circular cut-outs. Proceedings of the Institution of Civil Engineers 71(2): 845-862. 
Nishino, F. \& Okumura, T. 1968. Experimental Investigation of Strength of Plate Girders in Shear. Final Report, $8^{\text {th }}$ Congress of the International Association for Bridge and Structural Engineering (IABSE): 451-463.

Porter, D. M., Rockey, K. C. \& Evans, H. R. 1975. The collapse behaviour of plate girders loaded in shear. The Structural Engineer 53(8): 313-325.

Rockey, K. C. \& Skaloud, M. 1971. The Ultimate Load Behaviour of Plate Girders Loaded in Shear. International Association for Bridge and Structural Engineering (IABSE) Colloquium: Design of plate box girders for ultimate strength: 1-19.

Mohd Yazmil Md. Yatim*

Mohd Reza Azmi

Lau Yew Ling

Muhammad ‘Ariff Putra Ansaruddin Agus

Nur Farhana Nadira Sazali

Structures, Materials and Construction Management

Research Group

Department of Civil \& Structural Engineering

Universiti Kebangsaan Malaysia

43600 UKM Bangi, Selangor

Malaysia

*Corresponding author

Tel : : +603 89216202

E-mail : mymy@ukm.edu.my
Rockey, K. C., Evans, H. R. \& Porter, D. M. 1978. A design method for predicting the collapse behaviour of plate girders. Proceedings of the Institution of Civil Engineers 65(2): 85-112.

Shanmugam, N. E. \& Baskar, K. 2003. Steel-concrete composite plate girders subject to shear loading. Journal of Structural Engineering ASCE 129(9): 1230-1242.

Yoo, C. H. \& Lee, S. C. 2006. Mechanics of web panel postbuckling behaviour in shear. Journal of Structural Engineering ASCE 132(10): 1580-1589. 
